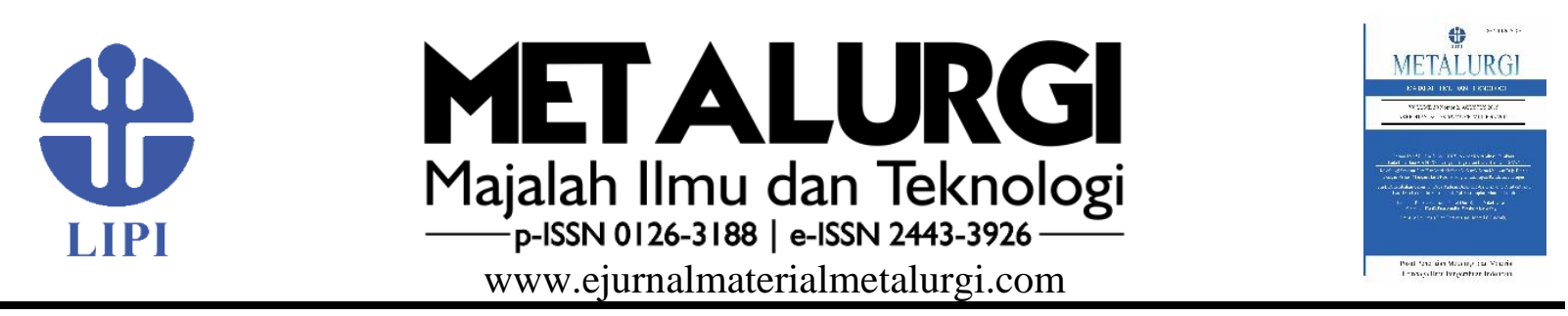

\title{
Pengaruh Perlakuan Hidrotermal Terhadap Morfologi, SIFAT OPTIK, DAN SIFAT LISTRIK LAPISAN TIPIS NANORODS ZnO
}

\author{
Lalu Suhaimi i,*, Akhmad Herman Yuwono ${ }^{b}$, Achmad Subhan ${ }^{c}$ \\ ${ }^{a}$ Teknik Metalurgi, Fakultas Teknik Universitas Teknologi Sumbawa \\ Jl. Raya Olat Maras, Kec. Moyo Hulu, Kab. Sumbawa, NTB, Indonesia \\ ${ }^{\text {b} D e p a r t e m e n ~ T e k n i k ~ M e t a l u r g i ~ d a n ~ M a t e r i a l, ~ F a k u l t a s ~ T e k n i k ~ U n i v e r s i t a s ~ I n d o n e s i a ~}$ \\ Universitas Indonesia, Depok, Indonesia 16424 \\ 'Pusat Penelitian Fisika - LIPI \\ Gedung 440-442, Kawasan PUSPITEK Serpong, Indonesia 15310 \\ *E-mail: lalu.suhaimi@uts.ac.id
}

Masuk Tanggal :02-11-2020, revisi tanggal:23-11-2020, diterima untuk diterbitkan tanggal : 27-11-2020

\begin{abstract}
Abstrak
Nanorods seng oksida (ZnO NRs) merupakan salah satu material semikonduktor yang telah banyak diaplikasikan di berbagai bidang. Pada penelitian ini, ZnO NRs telah berhasil ditumbuhkan di atas substrat ITO (indium thin oxide) dengan metode CBD (chemical bath deposition). Proses diawali dengan pembuatan larutan bibit menggunakan campuran ekimolar Zn-nitrat dan HMTA (hexamethylenetetramine) pada temperatur $0{ }^{\circ} \mathrm{C}$ selama satu jam dengan konsentrasi sebesar 0,02 M. Selanjutnya, pembuatan lapisan bibit dengan teknik spin coating. ZnO NRs ditumbuhkan dengan metode CBD pada temperatur $90{ }^{\circ} \mathrm{C}$ selama tiga jam untuk kemudian dilakukan perlakuan variasi, yaitu perlakuan dengan metode hidrotermal dan perlakuan dengan tanpa metode hidrotermal pada temperatur $150{ }^{\circ} \mathrm{C}$ selama tiga jam. Karakterisasi dilakukan menggunakan SEM (scanning electron microscope), XRD ( $x$-ray diffraction), UV-Vis dan four-point probe. Hasil SEM menunjukkan bahwa perlakuan hidrotermal mampu meningkatkan sebaran (coverage) nanorods di atas substrat yang lebih merata dan meningkatkan struktur vertikal nanorods. Hasil analisis XRD memperlihatkan material yang diberikan perlakuan hidrotermal mengalami peningkatan ukuran kristalit nanorods. Besarnya ukuran kristalit pada material dengan perlakukan variasi tanpa hidrotermal dan perlakuan dengan hidrotermal masing-masing sebesar 71,20 dan 165,70 nm. Perlakuan hidrotermal terhadap nanorods menyebabkan penurunan ukuran diameter dari 288,25 nm menjadi 125,82 nm. Nilai transmitansi material mengalami penurunan dengan adanya perlakuan hidrotermal yaitu 56,53\% menjadi 38,67\%. Perlakuan hidrotermal mampu menurunkan celah pita energi $\left(E_{g}\right)$ dari material, sedangkan material tanpa perlakuan hidrotermal nilai energi celah pita adalah sebesar $3,22 \mathrm{eV}$. Sementara itu, nilai celah pita energi $\left(E_{g}\right)$ setelah perlakuan hidrotermal sebesar 3,17 eV. Nilai resistivitas ZnO NRs dengan perlakuan hidrotermal sebesar $0,83 \times 10^{-4}$ $\Omega \mathrm{cm}$, sedangkan tanpa perlakuan hidrotermal adalah sebesar $1,13 \times 10^{-4} \Omega \mathrm{cm}$.
\end{abstract}

Kata Kunci: Nanorods seng oksida, chemichal bath deposition, hidrotermal

\begin{abstract}
Zinc oxide nanorods ( $\mathrm{ZnO} \mathrm{NRs}$ ) is a semiconductor material that has been widely applied in various fields. In this research, ZnO NRs were successfully grown on ITO (indium thin oxide) substrates by CBD (chemical bath deposition) method. The process begins with making a seed solution using an equimolar mixture of Zn-nitrate and HMTA (hexamethylenetetramine) at $0{ }^{\circ} \mathrm{C}$ for one hour with $0.02 \mathrm{M}$ concentration. Furthermore, making a layer of seeds using a spin coating technique. ZnO NRs were grown using the CBD method at $90{ }^{\circ} \mathrm{C}$ for three hours then treated with variations: are hydrothermal method treatment and non-hydrothermal method treatment at $150{ }^{\circ} \mathrm{C}$ for three hours. The materials were given characterization treatment using (scanning electron microscope), XRD ( $x$-ray diffraction), UV-Vis, and a four-point probe. SEM results showed that hydrothermal treatment increased the nanorods' coverage on the substrate to be more prevalently and improved the nanorods' vertical structure of the nanorods. The results of XRD analysis showed that materials given hydrothermal treatment experienced an increase in the crystallite size. The amount of crystallite size in the material treated with a variation of non-hydrothermal treatment and hydrothermal treatment was 71.20 and $165.70 \mathrm{~nm}$. Hydrothermal treatment of nanorods materials
\end{abstract}


decreased the diameter from $288.25 \mathrm{~nm}$ to $125.82 \mathrm{~nm}$. The transmittance value of the materials decreased in the presence of hydrothermal treatment, which is $56.53 \%$ to $38.67 \%$. The hydrothermal treatment reduced the energy bandgap (Eg) of the material, while the non-hydrothermal treatment showed a value of the Eg was $3.22 \mathrm{eV}$. Meanwhile, the value of Eg after hydrothermal treatment was $3.17 \mathrm{eV}$. The resistivity value of ZnO NRs with hydrothermal treatment was $0.83 \times 10-4 \Omega \mathrm{cm}$, while non-hydrothermal treatment was $1.13 \times 10-4 \Omega \mathrm{cm}$.

Keywords: zinc-oxide nanorods, chemical bath deposition, hydro-thermal

\section{Pendahuluan}

Salah satu material semikonduktor oksida yang menarik banyak perhatian para peneliti saat ini adalah seng oksida (zinc oxide, $\mathrm{ZnO}$ ) karena material ini memiliki sifat-sifat yang unik seperti energi celah pita (band gap energy) yang lebar sebesar $3,37 \mathrm{eV}$, mempunyai emisi ultraviolet yang kuat pada temperatur ruang karena memiliki energi ikatan elektron yang tinggi energi sebesar $60 \mathrm{meV}$, sehingga material tersebut banyak diaplikasikan pada teknologi terkini seperti laser semikonduktor UV biru, dioda pemancar cahaya, fotokatalis, pemanas transparan dan divais optoelektronik lainnya [1]-[3]. Sifat lain yang dimiliki oleh $\mathrm{ZnO}$ adalah biokompatibilitas, tingkat toksisitas yang rendah, mobilitas elektron yang tinggi, mudah untuk difabrikasi dan memiliki stabilitas kimia yang baik. Selain itu, nanorods $\mathrm{ZnO}$ memiliki daerah elektroaktif yang jauh lebih besar dibandingkan dengan ukuran bulknya disebabkan karena rasio permukaan terhadap volum yang tinggi pada skala nano, sehingga material ini menjanjikan untuk diterapkan di bidang biomedikal seperti biosensor dan elektrokimia sensor [4]-[7].

Seng oksida dalam bentuk nanostruktur satu dimensi (1-D) seperti nanorods telah banyak diteliti untuk berbagai aplikasi. Pada umumnya, metode yang digunakan dalam fabrikasi nanostruktur $\mathrm{ZnO}$ ada dua yaitu, wet chemical dan phase gas. Metode wet chemical lebih banyak digunakan untuk memfabrikasi nanorods $\mathrm{ZnO}$ dibandingkan dengan metode phase gas karena biayanya lebih terjangkau. Salah satu metode wet chemical yang banyak digunakan dalam fabrikasi nanorods $\mathrm{ZnO}$ adalah CBD (chemical bath deposition) karena metode ini dioperasikan pada temperatur rendah, berbiaya rendah, dan metodenya sederhana [8]. Pourshabana, dkk., telah berhasil mensintesis nanorods $\mathrm{ZnO}$ di atas substrat kaca dengan metode CBD. Penelitian ini dilakukan untuk melihat pengaruh konsentrasi larutan bibit pada lapisan bibit terhadap struktur, morfologi dan sifat optik nanorods $\mathrm{ZnO}$ di atas substrat kaca [9]. Penelitian lainnya yang dilakukan oleh Abdulrahman, dkk., telah berhasil menumbuhkan nanorods $\mathrm{ZnO}$ di atas substrat kaca mikroskop dengan melakukan variasi konsentrasi prekursor. Hasil dari penelitian ini menunjukkan bahwa perbedaan konsentrasi prekursor memiliki pengaruh yang signifikan terhadap pertumbuhan dan karakteristik nanorods $\mathrm{ZnO}$ [10].

Pada umumnya, sintesis nanorods $\mathrm{ZnO}$ menggunakan metode CBD belum mampu menghasilkan struktur vertikal tegak sempurna di atas substrat [11]. Struktur vertikal tegak sempurna dari rods di atas substrat dapat ditingkatkan dengan membuat lapisan bibit pada substrat. Selain itu, pembuatan lapisan bibit berfungsi sebagai dasar atau awal mula untuk pertumbuhan nanorods $\mathrm{ZnO}$ [12]. Sementara itu, Amoupur, dkk., telah berhasil meningkatkan karakteristik lapisan tipis seperti kualitas kristal, sifat listrik, sifat optik, dan morfologi dengan menerapkan proses post-annealing [13]. Pada penelitian lainnya yang dilakukan oleh Yuwono, dkk., tekanan pada proses post-hidrotermal mampu meningkatkan ukuran kristalit dan menurunkan celah pita energi dari nanopartikel $\mathrm{ZnO}$ [14]. Pada penelitian ini, dilakukan proses penumbuhan nanorods $\mathrm{ZnO}$ di atas substrat menggunakan metode CBD yang berlangsung pada temperatur rendah dan melihat pengaruh perlakuan hidrotermal dengan menggunakan tekanan uap air pada reaktor. Perlakuan hidrotermal ini diharapkan mampu meningkatkan struktur vertikal nanorods yang tumbuh di atas substrat.

\section{Prosedur Percobaan}

Proses pembuatan lapisan tipis nanorods $\mathrm{ZnO}$ dimulai dengan persiapan substrat sebagai medium penumbuhan nanorods $\mathrm{ZnO}$. Substrat yang digunakan pada penelitian ini yaitu kaca konduktor ITO (indium thin oxide). Substrat dibersihkan menggunakan deionized water, aseton, dan etanol masing-masing selama 480 detik kemudian dikeringkan. Setelah itu, dilakukan pembuatan larutan bibit. Pembuatan larutan bibit dilakukan menggunakan campuran ekimolar Zn-nitrat dan HMTA (hexamethylenetetramine) pada temperatur $0{ }^{\circ} \mathrm{C}$ selama satu jam dengan konsentrasi sebesar 0,02 M. Proses pembuatan larutan bibit dilakukan dengan melarutkan Zn-nitrat sebanyak 0,39 gr 
dan HMTA sebanyak 0,21 gr ke dalam beaker gelas yang berisi $100 \mathrm{ml}$ deionized water. Selanjutnya, senyawa tersebut dimasukkan ke dalam cool box yang telah berisi es batu selama satu jam untuk memperoleh larutan yang homogen.

Selanjutnya adalah pembuatan lapisan bibit menggunakan teknik spin coating dengan kecepatan $2000 \mathrm{rpm}$ selama 20 detik yang diawali dengan meneteskan larutan bibit ke atas substrat untuk kemudian didiamkan selama sepuluh menit agar larutan bibit tersebut terserap pada permukaan substrat. Setelah itu, kaca yang telah terlapisi bibit dianil dalam muffle furnace pada temperatur $200{ }^{\circ} \mathrm{C}$ selama 5 menit untuk meningkatkan adhesi antara lapisan bibit dengan substrat. Lapisan bibit yang telah dibuat selanjutnya diproses untuk menumbuhkan nanorods $\mathrm{ZnO}$ di atas substrat dengan cara menggantungkan substrat secara vertikal di dalam beaker glass yang telah berisi larutan ekimolar Zn-Nitrat dan HMTA dengan konsentrasi $0,02 \mathrm{M}$ pada temperatur $90{ }^{\circ} \mathrm{C}$ selama tiga jam. Setelah itu, substrat dicuci menggunakan deionized water kemudian dikeringkan di udara. Sampel yang sudah diberi perlakuan untuk proses penumbuhan akan diberi variasi perlakuan hidrotermal dan perlakuan nonhidrotermal. Proses hidrotermal dilakukan dengan meletakkan substrat menghadap sisi dasar reaktor hidrotermal pada temperatur $150{ }^{\circ} \mathrm{C}$ selama tiga jam. Hasil dari proses ini akan dilanjutkan dengan proses karakterisasi XRD ( $x$ ray diffraction), SEM (scanning electron microscope), UV-Vis dan four point probe untuk mengetahui sifat listrik sampel.

\section{Hasil dan Pembahasan}

\subsection{Lapisan Tipis Nanorods $\mathrm{ZnO}$ dengan Variasi Hidrotermal (ZnO_HT) dan Non- Hidrotermal (ZnO_NHT) \\ Gambar 1 memperlihatkan hasil} karakterisasi XRD (x-ray diffraction) dari lapisan tipis nanorods $\mathrm{ZnO}$ dengan variasi hidrotermal dan non-hidrotermal. Berdasarkan hasil karakterisasi XRD, terdeteksi dua puncak difraksi yang bersesuaian dengan puncak bidang kristal (002) dan (103) dari polikristalin $\mathrm{ZnO}$ dengan struktur wurtzite heksagonal berdasarkan JCPDS No. 36-1451, sedangkan puncak-puncak difraksi lainnya dikonfirmasi sebagai bidang bidang kristal dari substratnya. Selain itu, perbedaan pola difraksi sinar-x tampak antara material yang diberi perlakuan hidrotermal dengan material non-hidrotermal. Intensitas puncak bidang kristal (002) pada material $\mathrm{ZnO}$ yang diberikan perlakuan hidrotermal mengalami kenaikan. Hal ini menunjukkan bahwa nanorods $\mathrm{ZnO}$ pada material tersebut tumbuh secara vertikal sepanjang sumbu-z. Peningkatan intensitas ini berkorelasi dengan peningkatan kristalinitas nanorods $\mathrm{ZnO}$.

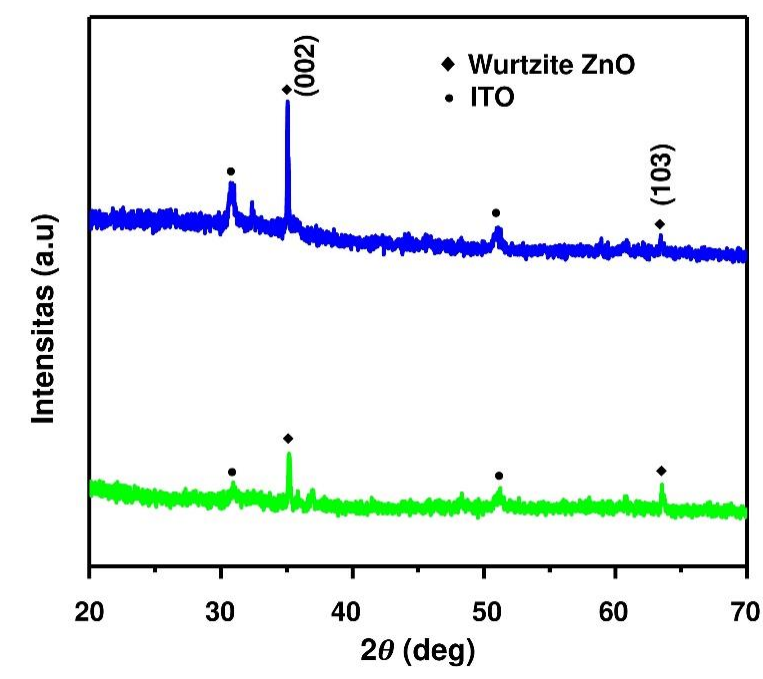

Gambar 1. Hasil karakterisasi XRD untuk material: (a) ZnO_HT (b) ZnO_NHT

Selain itu, puncak (002) yang semakin tajam menunjukkan adanya peningkatan ukuran kristalit nanorods $\mathrm{ZnO}$ dari $71,20 \mathrm{~nm}$ (sebelum perlakuan hidrotermal) menjadi 165,70 nm (setelah perlakuan hidrotermal) seperti ditunjukkan pada Gambar 2. Puncak intensitas yang lebih rendah berkorelasi dengan tingkat kristalinitas yang lebih rendah pula. Sementara itu, adanya spektra ITO (indium thin oxide) yang terlihat lebih dominan pada material dengan perlakuan hidrotermal disebabkan karena tidak optimalnya proses pembuatan lapisan bibit di atas substrat. Berdasarkan hasil penelitian yang dilakukan oleh Wang, dkk., memperlihatkan bahwa lapisan bibit pada sintesis nanostruktur $\mathrm{ZnO}$ nanorods dengan menggunakan metode hidrotermal merupakan pemicu pertumbuhan nanostruktur menjadi lapisan yang rapat dan merata di seluruh permukaan substrat [15].

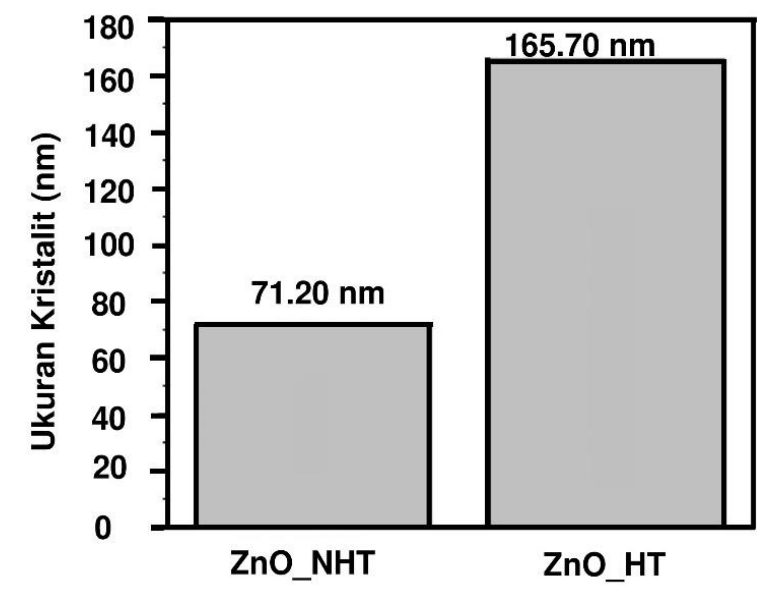

Gambar 2. Ukuran kristalit dari material $\mathrm{ZnO \_ HT} \mathrm{dan}$ ZnO_NHT 
Struktur morfologi penampang atas lapisan tipis nanorods $\mathrm{ZnO}$ sebelum dan sesudah proses hidrotermal diperlihatkan pada Gambar 3. Pada gambar tersebut, nanorods $\mathrm{ZnO}$ terlihat memiliki struktur batang heksagonal. Sebaran (coverage) nanorods dengan arah vertikal di atas substrat ITO setelah perlakuan hidrotermal lebih merata dan dominan dibandingkan dengan sebelum diberi perlakuan hidrotermal, serta nanorods tampak tumbuh dengan arah vertikal yang baik di atas substrat ITO. Selain itu, perlakuan hidrotermal terhadap nanorods menyebabkan penurunan ukuran diameter material yaitu dari $288,25 \mathrm{~nm}$ menjadi $125,82 \mathrm{~nm}$.
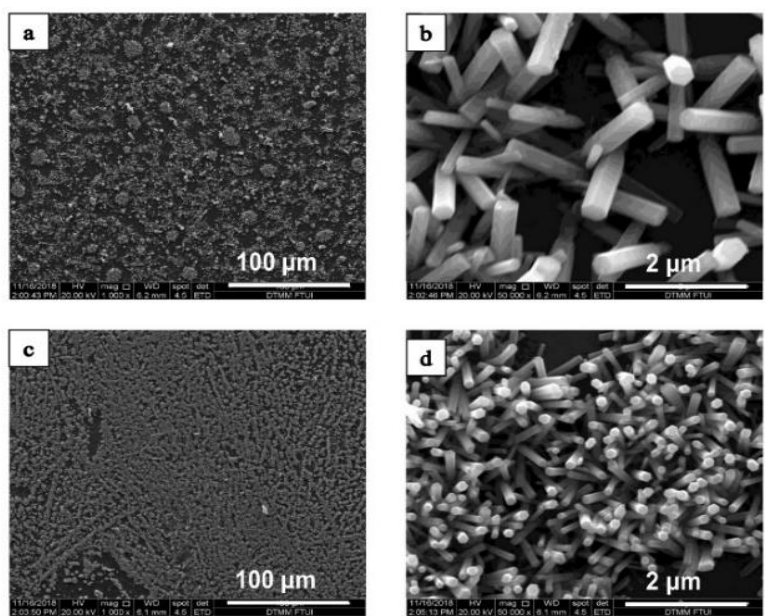

Gambar 3. Struktur morfologi penampang (a)-(b) ZnO_NHT dan (c)-(d) ZnO_HT

Sementara itu, distribusi ukuran diameter $\mathrm{ZnO}$ dengan perlakuan hidrotermal memiliki distribusi yang lebih seragam dibandingkan dengan material $\mathrm{ZnO}$ yang tidak diberi perlakuan hidrotermal seperti yang diperlihatkan pada Gambar 4.
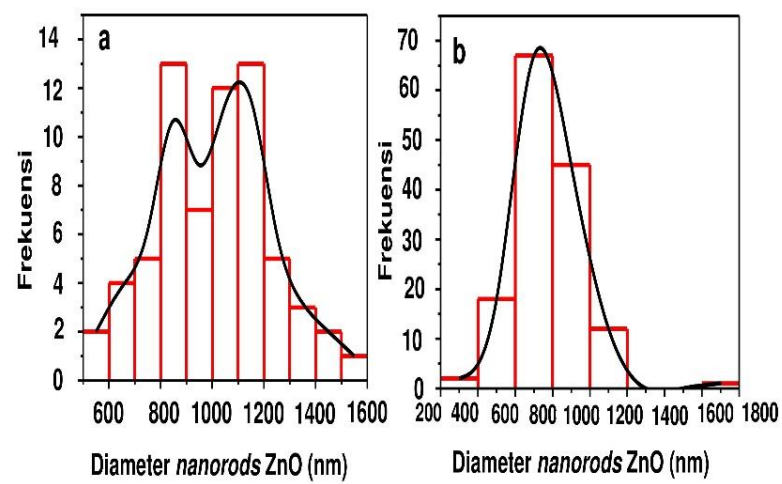

Gambar 4. Distribusi diameter nanorods $\mathrm{ZnO}$ (a) ZnO_NHT dan (b) ZnO_HT

Gambar 5 menunjukkan nilai transmitansi dari lapisan tipis nanorods $\mathrm{ZnO}$ dengan variasi tanpa hidrotermal (Gambar 5 (a)) dan hidrotermal (Gambar 5 (b)). Nilai transmitansi dari material $\mathrm{ZnO}$ mengalami penurunan dengan adanya perlakuan hidrotermal sehingga nilai transmitansi untuk material $\mathrm{ZnO}$ dengan variasi tanpa hidrotermal menjadi 56,53\%. Sementara itu, nilai transmitansi untuk $\mathrm{ZnO}$ dengan perlakuan hidrotermal adalah sebesar 38,67\%. Penurunan nilai transmitansi dari $\mathrm{ZnO}$ disebabkan oleh peningkatan sebaran (coverage) nanorods $\mathrm{ZnO}$ di atas substrat.

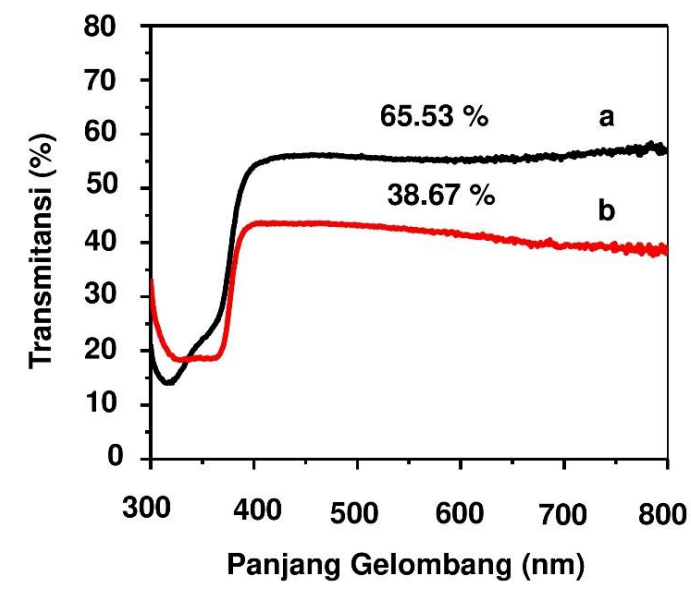

Gambar 5. Nilai transmitansi dari lapisan tipis nanorods ZnO: (a) ZnO_NHT; (b) ZnO_HT

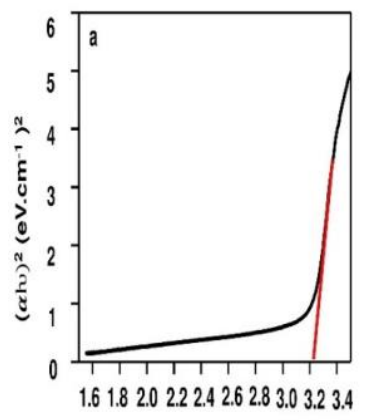

$\mathrm{ho}(\mathrm{eV})$

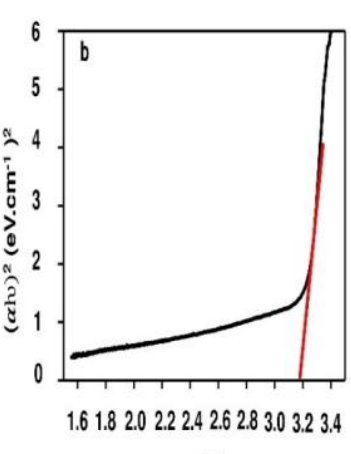

bu(eV)
Gambar 6. Kurva $(\alpha \mathrm{h} v)^{2}$ terhadap hv nanorods $\mathrm{ZnO}$ : (a) ZnO_NHT dan (b) ZnO_HT

Selain nilai transmisi, sifat optik lain yang dikaji pada penelitian ini yaitu nilai celah pita energi $\left(E_{g}\right)$. Gambar 6 menunjukkan nilai $E_{g}$ dari lapisan tipis nanorods $\mathrm{ZnO}$ dengan variasi tanpa hidrotermal dan dengan perlakuan hidrotermal. Berdasarkan kurva tersebut, perlakuan hidrotermal mampu menurunkan $E_{g}$ dari material. Material $\mathrm{ZnO}$ tanpa perlakuan hidrotermal memiliki nilai $E_{g}$ sebesar $3,22 \mathrm{eV}$, sedangkan nilai $E_{g}$ setelah perlakuan hidrotermal adalah sebesar 3,17 eV. Pada umumnya, salah satu faktor yang menyebabkan penurunan nilai $E_{g}$ adalah perbaikan dalam pertumbuhan kristal yang ditandai dengan naiknya ukuran kristalit. Hasil ini telah terkonfirmasi berdasarkan hasil analisis XRD sebelumnya, bahwa ukuran kristalit meningkat dengan variasi hidrotermal dan menurun tanpa perlakuan hidrotermal. Semakin rendah energi celah pita maka semakin rendah 
energi yang diperlukan untuk transisi elektronik. Dengan demikian, konsentrasi pembawa muatan bebas menjadi meningkat [16]. Oleh karena itu, energi celah pita yang rendah sangat berguna untuk meningkatkan konduktivitas listrik material karena konduktivitas listrik berbanding lurus dengan konsentrasi pembawa muatan.

Nilai resistivitas dan konduktivitas merupakan parameter untuk mengetahui sifat listrik dari material nanorods $\mathrm{ZnO}$. Keduanya memiliki nilai yang berkebalikan satu sama lain dan sangat dipengaruhi oleh konsentrasi serta mobilitas pembawa muatan. Berdasarkan hasil pengujian material $\mathrm{ZnO}$ menggunakan four-point probe, nanorods $\mathrm{ZnO}$ dengan variasi hidrotermal diperoleh nilai resistivitas sebesar $0,83 \times 10^{-4}$ $\Omega \mathrm{cm}$. Sementara itu, nilai resisitivitas $\mathrm{ZnO}$ tanpa perlakuan hidrotermal adalah sebesar $1,13 \times 10^{-4}$ $\Omega \mathrm{cm}$. Penurunan nilai resistivitas pada material $\mathrm{ZnO}$ dengan variasi hidrotermal diduga disebabkan oleh beberapa faktor. Pertama, meningkatnya keteraturan nanorods yang tumbuh di atas substrat ITO dengan adanya perlakuan hidrotermal sehingga menyebabkan penurunan hamburan elektron di nanorods [17]-[18]. Kedua, meningkatnya mobilitas pembawa muatan akibat peningkatan ukuran butir (kristalit) rata rata nanorods $\mathrm{ZnO}$, seperti yang telah diperlihatkan sebelumnya melalui analisis XRD dan SEM (scanning electron microscope). Ukuran butir yang meningkat menyebabkan kontak permukaan antar butir mengalami kenaikan sehingga mobilitas elektron menjadi lebih besar. Peningkatan mobilitas elektron menyebabkan peningkatan konduktivitas listrik, begitu pula sebaliknya [18]-[19].

\section{KeSimpUlan}

Nanorods $\mathrm{ZnO}$ telah berhasil ditumbuhkan di atas substrat ITO dengan metode chemical bath deposition. Pemberian perlakuan hidrotermal pada material $\mathrm{ZnO}$ mampu memperbaiki morfologinya. Hasil ini ditunjukkan berdasarkan foto SEM (scanning electron microscope) yang menunjukkan sebaran (coverage) nanorods di atas substrat meningkat dan struktur nanorods tumbuh secara vertikal. Hasil analisis XRD (x-ray diffraction) memperlihatkan bahwa intensitas puncak bidang kristal (002) pada material $\mathrm{ZnO}$ yang diberi perlakuan hidrotermal mengalami kenaikan. Puncak (002) yang semakin tajam menunjukkan adanya peningkatan ukuran kristalit nanorods. Besarnya ukuran kristalit pada material $\mathrm{ZnO}$ dengan variasi perlakuan tanpa hidrotermal dan perlakuan dengan hidrotermal masing-masing adalah sebesar 71,20 dan 165,70 nm. Perlakuan hidrotermal terhadap material $\mathrm{ZnO}$, nanorods $\mathrm{ZnO}$ menyebabkan penurunan ukuran diameter yaitu dari $288,25 \mathrm{~nm}$ menjadi $125,82 \mathrm{~nm}$. Nilai transmitansi dari material $\mathrm{ZnO}$ mengalami penurunan dengan adanya perlakuan hidrotermal yaitu $56,53 \%$ menjadi $38,67 \%$. Perlakuan hidrotermal mampu menurunkan celah pita energi (Eg) dari material $\mathrm{ZnO}$. Material $\mathrm{ZnO}$ tanpa perlakuan hidrotermal memiliki nilai $\mathrm{Eg}$ sebesar 3,22 eV, sedangkan nilai Eg setelah mendapat perlakuan hidrotermal adalah sebesar 3,17 eV. Nilai resistivitas nanorods $\mathrm{ZnO}$ dengan perlakuan hidrotermal sebesar $0,83 \times 10^{-4} \Omega \mathrm{cm}$, sedangkan tanpa perlakuan hidrotermal adalah sebesar $1,13 \times 10^{-4} \Omega \mathrm{cm}$.

\section{UCAPAN TERIMA KASIH}

Terima kasih kepada Direktorat Penelitian dan Pengabdian kepada Masyarakat Universitas Indonesia atas dukungan finansial melalui hibah penelitian PITTA Universitas Indonesia tahun 2018.

\section{Daftar Pustaka}

[1] S. A. Azzez, Z. Hassan, J. J. Hassan, M. S. Mukhlif, M. S. Mahdi, dan M. Bououdina, "Effect of temperature on hydrothermally grown high-quality single-crystals $\mathrm{Mg}$ doped $\mathrm{ZnO}$ nanorods for light-emitting diode application," J. Lumin., vol. 192, pp. 634-643, 2017. Doi: 10.1016/j.jlumin.2017.07.050.

[2] N. D. Raskar, D. V. Dake, V. A. Mane, E. Stathatos, U. Deshpande, dan B. Dole, "One step synthesis of vertically grown Mn-doped $\mathrm{ZnO}$ nanorods for photocatalytic application," J. Mater. Sci. Mater. Electron., vol. 30, pp. 1088610889, 2019. Doi: 10.1007/s10854-01901433-7.

[3] A. H. Yuwono, L. Suhaemi, N. Sofyan, D. Dhaneswara, G. Ramahdita, A. Sholehah, dan C. Hudaya, "Nanostructural growth investigation of Zno nanorods derived from chemical bath deposition for transparent heater application," Int. J. Technol., vol. 9, no. 6, pp. 1216-1224, 2018. Doi: 10.14716/ijtech.v9i6.2452.

[4] M. Marie, A. Manoharan, A. Kuchuk, S. Ang, dan M. O. Manasreh, "Vertically grown zinc oxide nanorods functionalized with ferric oxide for in vivo and nonenzymatic glucose detection," Nanotechnology, vol. 29, no. 11, 2018. Doi: 10.1088/1361-6528/aaa682.

[5] N. S. Ridhuan, K. Abdul Razak, dan Z. Lockman, "Fabrication and 
characterization of glucose biosensors by using hydrothermally grown $\mathrm{ZnO}$ nanorods," Sci. Rep., vol. 8, 2018. Doi: 10.1038/s41598-018-32127-5.

[6] R. Ahmad, M. S. Ahn, dan Y. B. Hahn, "Fabrication of a non-enzymatic glucose sensor field-effect transistor based on vertically-oriented $\mathrm{ZnO}$ nanorods modified with Fe2O3," Electrochem. commun., vol. 77, pp. 107-111, 2017. Doi: 10.1016/j.elecom.2017.03.006.

[7] S. K. Naveen Kumar, A. Akshaya Kumar, A. A. Aniley, S. Bhansali, dan R. E. Fernandez, "Hydrothermal growth of zinc oxide ( $\mathrm{ZnO})$ nanorods (NRs), structural, and chemical composition studies for $\mathrm{pH}$ measurement sensor applications," ECS Trans., vol. 8, no. 1, pp. 437-447, 2018. Doi: 10.1149/08801.0437ecst.

[8] M. Willander, Zinc oxide nanostructures: Advances and applications. 2014.

[9] E. Pourshaban, H. Abdizadeh, dan M. R. Golobostanfard, "ZnO nanorods array synthesized by chemical bath deposition: Effect of seed layer sol concentration," Procedia Mater. Sci., vol. 11, pp. 352-358, 2015. Doi: 10.1016/j.mspro.2015.11.124.

[10] A. F. Abdulrahman, S. M. Ahmed, N. M. Ahmed, dan M. A. Almessiere, "Enhancement of $\mathrm{ZnO}$ nanorods properties using modified chemical bath deposition method: Effect of precursor concentration," Crystals, vol. 10, no. 386, 2020. Doi: 10.3390/cryst10050386.

[11] A. Sholehah, A. H. Yuwono, N. Sofyan, C. Hudaya, dan M. I. Amal, "Effect of posthydrothermal treatments on the physical properties of $\mathrm{ZnO}$ layer derived from chemical bath deposition," Int. J. Technol., vol. 8, no. 4, pp. 651-661, 2017. Doi: 10.14716/ijtech.v8i4.9487.

[12] R. H. Zhang, E. B. Slamovich, dan C. A. Handwerker, "Controlling growth rate anisotropy for formation of continuous $\mathrm{ZnO}$ thin films from seeded substrates," Nanotechnology, vol. 24, no. 195603, $2013 . \quad$ Doi: 10.1088/09574484/24/19/195603.

[13] E. Amoupour, A. Abdolahzadeh Ziabari, H. Andarva, dan F. E. Ghodsi, "Influence of air/N2 treatment on the structural, morphological and optoelectronic traits of nanostructured ZnO:Mn thin films," Superlattices Microstruct., vol. 65, pp. 332-343, 2014. Doi: 10.1016/j.spmi.2013.11.014.

[14] A. H. Yuwono, D. Kurniawan, N. Sofyan,
G. Ramahdita, dan A. Sholehah, "Effect of pressure in post-hydrothermal treatment on the nanostructural characteristics of $\mathrm{ZnO}$ nanoparticles," Int. J. Technol., vol. 7, no. 3, pp. 424-430, 2016. Doi: 10.14716/ijtech.v7i3.2990.

[15] Z. L. Wang, "Zinc oxide nanostructures: Growth, properties and applications," $J$. Phys. Condens. Matter, vol. 16, pp. R829R858, 2004. Doi: 10.1088/09538984/16/25/R01.

[16] N. K. Bakirhan dan S. A. Ozkan, "Quantum dots as a new generation nanomaterials and their electrochemical applications in pharmaceutical industry," in Handbook of Nanomaterials for Industrial Applications, pp. 521, 2018.

[17] Y. Y. Chen, C. L. Chen, P. C. Lee, dan M. N. Ou, "Fabrication, characterization and thermal properties of nanowires," in Nanowires - Fundamental Research, pp. 277, 2011.

[18] E. Karaköse dan H. Çolak, "Effect of substrate temperature on the structural properties of $\mathrm{ZnO}$ nanorods," Energy, vol. 141, pp. 50-55, 2017. Doi: 10.1016/j.energy.2017.09.080.

[19] R. J. Hong, X. Jiang, B. Szyszka, V. Sittinger, dan A. Pflug, "Studies on $\mathrm{ZnO}$ :Al thin films deposited by in-line reactive mid-frequency magnetron sputtering," Appl. Surf. Sci., vol. 207, pp. $341-350$, 2003. Doi: 10.1016/S01694332(02)01525-8. 